\title{
Insights into the construction of cultural realities: Foreign newspaper discourses about the burkini ban in France
}

\author{
Ethnicities \\ Mélodine Sommier, Erasmus University Rotterdam
}

\begin{abstract}
The burkini ban introduced by several French coastal cities in August 2016 caused a great stir in France and abroad. Discussions were mostly articulated around the topics of secularism, religion, and national identity and values. This study examines foreign perspectives on the burkini ban in France to gain insights into the construction of cultural realities. Informed by Cultural Studies and Critical intercultural communication, this study approaches the construction of cultural realities by investigating the articulation of similarities and differences. A thematic analysis of newspaper articles $(N=167)$ from the United States, Canada, the United Kingdom and the Republic of Ireland was conducted to identify the categories evoked to construct similarities and differences. Findings indicated subtle shifts between old and refined commonalities. Throughout the data, France was cast away and represented as 'the deviant other' while Muslims and Islam were associated with representations of 'us'. However, underlying tensions indicated ambivalence in the redefinition of symbolic differences and similarities. Specifically, the figure of the Western Muslim and the construction of the burkini as 'appropriate difference' suggested the persistence of hierarchical relations between 'us' and 'them'. Cultural realities therefore appeared to be both liquid and solid. In addition, findings underlined the dialogic construction of cultural realities as differences and similarities were constructed at different levels (national and transnational) that became meaningful through their interactions.
\end{abstract}

Keywords: Cultural reality, media representations, Muslims, the West, France, burkini ban, critical intercultural communication, similarity, difference

\section{Introduction}

In the summer of 2016, several mayors in France forbade the wearing of the burkini on public beaches (see timeline of the main events in Table 1 below). Politicians instating the ban mentioned the recent terrorist attacks, the concept of secularism, and French cultural values to 
justify prohibiting the wearing of the burkini on public beaches (The Guardian, 2016a). The ban sparked controversy in and outside of France. However, opposition to the ban seemed to be stronger abroad than in France where initial oppositions were mostly limited to human rights associations. The ban was widely denounced abroad and associated with criticisms towards what was perceived as a generally harmful atmosphere in France (Courrier International, 2016).

Table 1. Overview of the main events related to the burkini ban in France.

\begin{tabular}{cl}
\hline \multicolumn{1}{c}{ Date } & \multicolumn{1}{c}{ Description of the events } \\
\hline 12 August 2016 & First burkini ban coming into effect in the city of Cannes \\
\hline 23 August 2016 & $\begin{array}{l}\text { A woman wearing a burkini on the beach in Nice was } \\
\text { apprehended by policemen and asked to remove her outfit. The } \\
\text { photograph of the situation was widely spread in social and } \\
\text { traditional media. }\end{array}$ \\
\hline 12-26 August 2016 & 31 additional cities in France implemented the ban \\
\hline 26 August 2016 & The State Council (Conseil d'Etat) suspended the burkini ban \\
\hline 2-5 September 2016 & $\begin{array}{l}\text { Dialog between New York Times } \text { and Prime Minister Manuel } \\
\text { Valls through the pages of the Huffington Post }\end{array}$ \\
\hline
\end{tabular}

This study focuses on the burkini ban because of its resonance across countries and in the media, as well as the topics brought up in relation to it. Discourses about the burkini ban touched upon a variety of notions ranging from culture, religion, secularism, Islam, the West, and collective identities. Exploring the articulation of these issues to construct impressions of sameness and difference can therefore offer relevant insights into the construction of cultural realities. This study draws on previous research from cultural studies and critical intercultural communication about media representations and post-racial expressions of racism in the media. Focusing on newspaper discourse about the burkini ban, this article poses the following questions:

1. What differences and similarities were mentioned in the articles collected? 
a. Around which notions were similarities and differences constructed?

b. With/against whom were similarities and differences constructed?

The data $(N=167)$ were collected from eight newspapers from four countries (United States, Canada, Republic of Ireland, and United Kingdom) and analyzed using thematic analysis. By choosing newspapers from abroad, this study sets out to explore how the notions of similarity and difference were utilized in the data when talking about the burkini ban implemented in France. Findings indicate subtle articulations of existing and new oppositions between $u s$ and them. Re-negotiations of existing categories draw attention to (i) the different levels (national and transnational) coming into play, (ii) the solid and fluid aspects involved in constructing cultural realities, (iii) and overall dialogic process.

\section{Theoretical background}

\section{Constructing cultural realities}

Polemics about the burkini ban touched upon issues ranging from national identities and values, to culture and religion. This event therefore stands as a relevant case to examine processes associated with the construction of cultural realities. Exploring cultural realities builds on postmodern assumptions about the notion of culture being a fluid, discursive and interactional resource that 'exists only insofar as it is performed' (Baumann, 1996: 11). From that perspective, culture is associated with the construction of symbolic similarities and differences used at individual and institutional levels to include as well as exclude (Dervin and Risager, 2015; Piller, 2011; Sommier, 2016). This study focuses on newspaper discourses given the explicit role of the press to construct imagined communities. As Anderson (1991) argued, media contribute to 
convey a sense of similarity among individuals through the common practices and knowledge they share. This sense of commonality comes hand in hand with the construction of differences and barriers with others (De Cillia et al., 1999). Exploring newspaper discourse supposes that symbolic similarities and differences are constructed at the national level. Nevertheless, representations of national imagined communities can be diverse and latent. De Cillia et al. (1999: 169) point out that 'The term "Austrian nation" often does not occur explicitly in [their] data'. National identity and representation are typically constructed in more implicit and complex ways. The authors, for instance, point out the complementary use of references to both national culture (Kulturnation) and national institutions (Staatsnation) (De Cillia et al., 1999). Holliday (2016) also emphasizes the interplay between individual and institutional discourses in constructing cultural realities. Studies looking at the construction of cultural realities have revealed complex interplays between existing static representations and their appropriations by individuals and across discourses. These research paths expose the limits of 'methodological nationalism' (Holliday, 2010: 166) and highlight the importance of inductively uncovering the various meanings attached to cultural realities (Sommier, 2016). For this reason, this study focuses on the articulation of differences and similarities as a way of identifying what (and how) cultural realities are constructed in the newspaper articles selected for analysis.

\section{Secularism in France}

Some of the mayors who passed municipal orders argued that wearing the burkini on public beaches was a violation of the principle of secularism. This argument was criticized for misinterpreting the law that forbids (mostly civil servants) from displaying religious affiliations in public services but not in public places (Veille, 2016). However inaccurate the claim was, it 
draws attention to the salience of secularism in the public and political debate in France. The system of separation of State and Church in France (laïcité) is intertwined with numerous societal, cultural and political issues, which makes it a complex and often polemical topic. Several studies have pointed out the pitfalls of this system and drawn attention to the unequal representations it can sustain. Researchers have cast light on the bias of secularism in France towards Catholicism and the concomitant pressures it puts on Islam and Muslims (Adrian, 2009; Bhandar, 2009; Doyle, 2011). Critiques have also discussed the embeddedness of French secularism in republicanism which emphasizes uniformity as a means to achieve equality regardless of origins, religion, or beliefs (Brubaker, 1992). This framework typically stands in opposition to multiculturalism and the recognition of official minorities (Baubérot, 2007). It is based on this framework that any statistics related to religious or ethnic belonging are forbidden in France (Cervulle, 2013). The emphasis placed on uniformity has, however, been criticized for creating unattainable integration goals and deepening inequalities (Hancock, 2008; Raveaud, 2008).

Jugé and Perez (2006) argue that uniformity, like universality, often mirrors the status quo and lifestyle of the majority, which hints at a larger problematic associated with color-blind ideology. Previous studies have pointed out the paradoxical fear of communitarianism in France that blames minorities for identifying as communities while dominant discourses tend to construct them as such (Geisser and Zemouri 2007; Sommier, 2017). This is particularly problematic for religious minorities who stand out in contrast to the invisible secular majority (Sommier, 2017). The prominent (yet false) representation of secularism as inherently and originally French (Baubérot, 2007; Baubérot and Milot, 2011) also contributes to tying laïcité and French identity together. The articulation of differences in France through the lenses of 
religion and secular practices echoes racial oppositions inherited from the colonial period. The opposition between Muslims and French is indeed reminiscent of that between Caucasian French, and Arabs, Maghrebi, or North Africans (Deltombe and Rigouste, 2006; Fellag, 2014).

These differences have been further emphasized by the political use of secularism in France, as illustrated by the burkini case. As an important national symbol, secularism has been woven into political agendas to defend specific perceptions of the nation and its identity. The National Front has very vocally associated secularism with national identity and traditions, and with opposition to Islam (Laoukili, 2005). The use of secularism in discourse to construct enemies dates further back and indicates shifts in society. Baubérot (2007) explains how oppositions went from antagonisms between secularism and Catholicism to hostilities between secularism and Islam. The latter opposition has been crystallized in the opposition towards the veil which has defined much of the polemics associated with secularism in France since the end of the 1980s.

\section{Representations of Islam in the media and expressions of racisms}

Discourses circulating in France about religion, and the status of Muslims in particular, are embedded in larger representations about Islam. Events in the past 20 years have been associated with negative discursive dynamics whereby Islam and terrorism are often conflated (Vanparys et al., 2013). Previous studies have drawn attention to the role played by media discourse in conveying biased and monolithic representations of Muslims (Saeed, 2007). Numerous studies have focused on representations of Islam and Muslims in European media. Their findings emphasized ways in which Muslims tend to be constructed as different by emphasizing Islam as 
foreign, dangerous, and overall at odds with European imagined communities (see e.g. Miera and Sara Pala, 2009; Moore et al., 2008; Poole, 2002; Richardson, 2010).

These representations are relevant to consider in light of the shifts that have characterized expressions of racism. Scholars have pointed out the renewal of racist discourses that moved from racial and biological claims to ethnic and cultural arguments (Lentin, 2004; Mason, 2000). Within these discourses, the construction of sameness is not articulated around explicit mention of racial similarities. Instead, the emphasis is placed on the cohesiveness of the imagined community and ideas of cultural similarities (Gilroy, 1992; Hall et al., 1992). This shift is further supported by discourses entrenched in Orientalism (Said, 1978) and that deploy ideas about a Clash of civilizations (Huntington, 1996) between the West and the Rest (Hall, 1992). Such discourses underline the symmetry between racism intertwined with colonialism and concepts of biological race, and current forms of cultural racism relying on cultural incompatibility between white majorities and Muslims. Construction of differences through the lens of national identity, representations of Muslims as others, and a sense of threat associated with the conflation of Islam and terrorism have laid the grounds for predatory identities. Appadurai (2006: 52) explains that the discursive logics associated with the emergence of predatory identities:

are based on claims about, and on behalf of, a threatened majority. In fact, in many instances, they are claims about cultural majorities that seek to be exclusively or exhaustively linked with the identity of the nation.

Appadurai's discussion of predatory identities underlines the relevance of investigating which concepts are brought up to construct differences and similarities. Polemics surrounding the burkini ban echoed tensions about representations of Muslims and relations between $u s$ and them. Exploring media discourses about this event therefore offers opportunities to explore lines 
along which difference and similarity are constructed, which draws attention to wider processes of constructing cultural realities.

\section{Data and methods}

Data

Data $(N=167)$ were collected from eight newspapers circulating in the following four different countries: United States, Canada, Republic of Ireland, and United Kingdom. These countries were selected for data collection because of their relative (cultural, historical, political, and economic) proximity with France and out of convenience in order to collect data in the English language. For each country selected, the newspaper with the highest circulation rate as well as one newspaper of record were used to collect data. Combining these two types of outlets enabled collection of data that would be somewhat representative of discourses circulating within each country on the issue of the burkini ban in France. Using newspapers known for their editorial lines and prominent opinion pieces moves away from ideas of representativeness. Instead, it offers a glimpse into the stances that were explicitly taken in order to understand what arguments were perceived as legitimate responses to the situation in France. Table 1 below presents an overview of the papers chosen and of their political leanings. Titles marked with an asterisk have the highest circulation rates.

Table 2. Newspapers used for data collection.

\begin{tabular}{|c|c|c|c|}
\hline USA & Canada & Republic of Ireland & $\mathbf{U K}$ \\
\hline USAToday* & Toronto Star* & Irish Independent* & Daily Telegraph* \\
\hline (centre) & (liberal) & (conservative) & (conservative) \\
\hline New York Times & The Globe and Mail & The Irish Times & The Guardian \\
\hline
\end{tabular}


(liberal)

(liberal / progressive

(liberal)

(centre-left)

conservative)

Articles published between August 12 and August 30 were collected directly from the newspaper websites using the keyword 'burkini'. The time frame for data collection corresponds to the major events that punctuated the burkini polemic in France. Table 1 in the introduction presented a detailed overview of the main events that characterized the burkini polemic in France in the summer of 2016. Specifically, data were collected from the day the first burkini ban came into effect in the city of Cannes (August 12) until a few days following the decision by the State Council (Conseil d'Etat) to suspend the burkini ban (August 26). Table 3 below indicates the overall number of articles collected per newspaper and country.

Table 3. Number of articles collected per newspaper and country.

\begin{tabular}{|c|c|c|c|c|c|c|c|}
\hline \multicolumn{2}{|c|}{ USA } & \multicolumn{2}{c|}{ Canada } & \multicolumn{2}{c|}{ Republic of Ireland } & \multicolumn{2}{c|}{ UK } \\
\hline USAToday & NYT & $\begin{array}{c}\text { Toronto } \\
\text { Star }\end{array}$ & $\begin{array}{c}\text { The Globe } \\
\text { and Mail }\end{array}$ & $\begin{array}{c}\text { Irish } \\
\text { Independent }\end{array}$ & $\begin{array}{c}\text { The Irish } \\
\text { Times }\end{array}$ & $\begin{array}{c}\text { Daily } \\
\text { Telegraph }\end{array}$ & $\begin{array}{c}\text { The } \\
\text { Guardian }\end{array}$ \\
\hline 12 & 41 & 11 & 9 & 26 & 17 & 12 & 39 \\
\hline \multicolumn{2}{|c|}{53} & \multicolumn{2}{|c|}{20} & \multicolumn{2}{c|}{43} & \multicolumn{2}{c|}{51} \\
\hline
\end{tabular}

\section{Analysis}

Data were analyzed using thematic analysis in order to explore in depth which elements were used to construct similarities and differences. A three-step coding approach was used that included open, axial, and selective coding stages (Boeije, 2010). This approach ensured a systematic and iterative reading of the data, which is a critical aspect for internal validity (Silverman, 2011). The different steps of the analysis enable a progression from linear coding focused on overt meanings to an integrated reading of the data that uncovers implicit meanings 
and connotations. The very first step consisted of reading the whole data set and taking notes about the issues perceived as relevant in the articles. Following this preliminary stage, codes were systematically assigned by reading all of the articles collected and constantly navigating between data and codes to evaluate and negotiate repetitions and overlaps. During the axial coding phase, all codes and associated fragments from the data were organized into a common file in order to identify and gather similar elements. The following thematic groupings were created at this stage:

- Singling out France (laïcité and religions in France, history of the country, stereotypes and jokes, political life and debates);

- Islam and Muslims (discriminations in France, immigration and integration, Muslim voices, talking on behalf of Muslims, Muslim women, Muslim practices);

- Entities, groups, communities (national representations, Europe, feminists, oppressed versus elites worldwide, people outside of France, Western values);

- $\quad$ Terrorism (past events, fueling new attacks).

In the last phase, codes, thematic groupings, fragments from the data and all notes made during the analysis were read through again. This process enabled comparing and contrasting the emerging analysis with the raw data to ensure that decisions made throughout the process were coherent (Boeije, 2010). Two main themes were identified as underlying and connecting the thematic groupings developed in the preceding phase. Namely, the construction of France as the deviant case and the idea of 'appropriate difference' were identified as significant themes through which differences and similarities were articulated in the data.

\section{Findings}


The coverage of the burkini ban in France offered insights into the (re)negotiations of meanings and oppositions. Specifically, what it means to be French, Muslim, and to belong to the West were actively discussed in the data. Overall, findings suggest that France was cast away and represented as 'them' while the idea that Muslims belong with 'us' was reinforced. However, underlying tensions indicate ambivalence regarding the redefinition of symbolic differences and similarities. The construction of the burkini as an 'appropriate difference' and the preservation of similarities with France indicate a complex interplay between persistence of established representations and emergence of new groupings. The two main themes along which differences and similarities were constructed in the data (i.e. the construction of France as the deviant case and the idea of 'appropriate difference') will be presented in detail after discussing differences and similarities among the newspapers used for data analysis.

\section{Similarities and differences among newspapers}

The vast majority of the articles criticized the burkini ban and discourses among newspapers were fairly homogeneous. A few discrepancies were, however, identified between the four newspaper of records (more liberal) and the four newspapers with the highest circulation rates, (more conservative with the exception of the Toronto Star). Throughout the data, only four articles out of 167 supported the ban. All four articles were published in the more conservative outlets (i.e. Mortimer, 2016, USAToday; Pearson, 2016, Daily Telegraph; Woods, 2016a, Daily Telegraph; Woods, 2016b, Irish Independent) therefore echoing their traditional editorial line. The same newspapers also published pieces aligned with discourses circulating in the rest of the data and criticizing the ban. However, articles published in the more conservative newspapers tended to give more importance to criticizing France than to including Muslims. On the other 
hand, the newspapers of records (i.e. The New York Times, The Guardian, The Irish Times, The Globe and Mail) integrated both strategies of excluding France and including Muslims. The more multifaceted discursive strategies used in the newspapers of record could result from their liberal political leaning, editorial tradition, as well as the fact that they published more articles overall (106 out of 167). Discrepancies between the newspapers could suggest that the burkini ban was widely criticized (and so was France for implementing it), but that the validating of the burkini and welcoming of Muslims was limited to a (more liberal) fringe of the media.

\section{Constructing France as the deviant case}

Throughout the data, the criticisms were targeted at the ban but also at France for implementing it. In numerous occasions, the burkini ban was presented as a typical French incident. Many articles pinpointed elements of the French society that would illustrate how and why the burkini ban was happening in France. This process of essentializing the burkini ban as an instance of Frenchness was supported by (i) the representation of laïcité as a French exception intertwined with (ii) references to the past and French history, as well as (iii) the use of French clichés.

Many articles criticized French secularism by presenting it as an institutionalized form of discrimination, as in the following extract:

It may seem a minor point [the misunderstood difference between public space and public services] but it is crucial in attempting to understand how the law allows Muslim women in France to be dehumanized. (Delphy, 29 August 2016, The Guardian, my emphasis)

Thus, as in most discourses since the 1990s (Baubérot, 2007), laïcité was presented in the data as a French exception, 'a concept for which there is no English translation' (Rubin, 17 August 2016, New York Times). For this reason, many articles contained explanatory paragraphs about the origin and workings of the French secularism system. Recurrent references to the past 
constructed laïcité, and its product, the burkini ban, as intrinsically French, especially through the mentioning of clichéd events such as the Revolution and Enlightenment. Overall, references to the past tended to position the burkini ban in a logical and historical line of events. Thus, the past sometimes provided irrevocable explanations for current events. Impressions of a cyclic process further presented the burkini ban as an inescapable continuation of the past:

This began in 1989 with the so-called affaire du foulard ('affair of the scarf'), in which three French schoolgirls were suspended for refusing to remove their head coverings. Ostensibly, this was because the scarves were visible religious symbols and thus ran afoul of the French rule of laïcité, or secularism. But laïcité had been on the books since 1905, with head scarves nonetheless by and large permitted. Head scarves in schools returned to the national spotlight in 1993 and 1994, as the French authorities worried that young men from Algerian immigrant families would join the Islamist insurgency in Algeria. After the terrorist attacks of Sept. 11, 2001, veils were once again a focal point for fears of Muslim communities that were isolated from mainstream French society and culture. (Taub, 18 August 2016, The New York Times, my emphasis)

The emphasis placed on French history and the past presented the burkini ban as a result of existing structures and traditions. Thus, the burkini ban was not presented as creating new problems but was connected with long-lasting societal problems:

the burkini has become a new dividing line in France's increasingly fraught relationship with its Muslim population. (Rubin, 17 August 2016, The New York Times, my emphasis)

this reaction to the burkini seems over the top and may further alienate the country's Muslim population. (Khan, 24 August 2016, The Globe and Mail, my emphasis)

The problems presented in the data were typically associated with the idea of French exception.

The idea of France facing a unique situation was conveyed through different arguments, from terrorism, immigration, and religious practices, to jokes and stereotypes. The following extract illustrates the depiction of France as an exception regarding the status of religion:

Religious clothing is particularly sensitive in France, where an unusually large part of the population has no religious affiliation, and where the first provision in the constitution says France is a 'secular Republic'. (Irish Independent, 26 August 2016) 
Several other articles used more humorous tone to construct the burkini ban as an instance of Frenchness by building on an existing repertoire of popular jokes and stereotypes. The following quote illustrates the use of clichés about the assumed status of sensuality and sexuality in France:

The French beach, after all, is sacred ground, where the female form is religiously flaunted and fawned upon. It's no coincidence that the world first discovered Brigitte Bardot sprawled out on le sable in a movie called And God Created Woman. So perhaps nothing constitutes more of an affront to the French way of life than the sight of a burkini on the Riviera. (Yakabuski, 22 August 2016, The Globe and Mail)

Representation of the burkini ban as inherently French hints at typical processes of stereotyping and essentializing that "[set] up a symbolic frontier between the "normal" and the "deviant", the "normal" and the "pathological".' (Hall, 1997: 258). Discourses about the burkini ban in the data used and reproduced essentialist views of French cultural reality by tapping into (popular, media, academic) knowledge about France. The condemnation of the burkini ban seemed to rely on a discursive shift whereby characteristics of the French exception, especially its relation with religion, turned from unique to deviant and pathological. Explaining the burkini ban as an illustration of Frenchness enables rejection not only of the ban but also of France. Relying on and reproducing essentialized representations of France therefore facilitates its exclusion while allowing to define what characterizes the rest of 'us'. The construction of France as the deviant case was further supported in the data by articles explicitly condemning France and the theme of French decline.

In contrast with humorous comments mentioned previously, sharp criticisms were voiced in the data. Words used to criticize the burkini ban were often very strong ('what complete bunk' (The Globe and Mail, 24 August 2016); 'ridiculous bans' (USAToday, 28 August 2016); 'The images are preposterous as well as ugly' (The Guardian, 24 August 2016b), as several argued 
that 'France has dug itself into a hole it needs to climb out of quickly' (Nougayrède, 26 August 2016, The Guardian). Articles also drew attention to the responsibility of France in fueling terrorist attacks because of the burkini ban. Unequivocal condemnations of France created a sharp division between 'us', those passing the judgment, and France, the defendant. This separation was further validated through the theme of French decline that emphasized the values betrayed by France and that used to define it (when it belonged with 'us'). The burkini ban was thus presented in the data as 'a sad sign of liberalism going backwards in France' (Ebner, 27 August 2016, Irish Independent). France was urged to 'recommit itself to combating prejudice against Muslims' by reconnecting with the values that shaped it: 'Paris was not built on backwardness or barbarism or misogyny. Its luminous appeal to all humanity stems from the Enlightenment' (Cohen, 18 August 2016, The New York Times). The theme of French decline enabled pointing out what no longer corresponds to France while underlining what still characterizes 'us'.

The theme of French decline was also conveyed through the parallel made between France today and conservatives from the past, for instance those who first opposed the bikini. In addition, France was associated with current conservative figures that are typically presented as 'our' enemies today. Comparisons with Saudi Arabia, Iran, Islamic extremists, Taliban and 'extremist religionist men' (Mallick, 29 August 2016, Toronto Star) in general emphasized representations of France as deviant. By posing the following question: 'How is France, with its national commitment to secularism, any different from Saudi Arabia, with its national religion of Islam?' (USAToday, 28 August 2016), these articles essentially posed the question of whether France still belongs with 'us'. 


\section{The burkini as 'appropriate difference'}

There seemed to be an inclination across data to refer to an imagined community beyond the national scope. Similarities were indeed suggested across borders as the burkini ban was assumed to have caused 'shock and anger worldwide' (The New York Times, 26 August 2016). Similarities were suggested among de-territorialized communities with an emphasis on the people (versus the elites embodied mostly by politicians and to a lesser extent by the media), minorities around the world, and women's right in particular:

What is it about women's swimwear and more generally women's attire that over and over in history has attracted controversy and impelled societies to legislate or regulate women's choices? Historians, sociologists and anthropologists have argued about it for decades, but the seemingly simplistic statement that women's bodies are a battleground has some truth to it. Formally or informally, men (primarily) have been making rules about women's attire for a very long time. (Rubin, The New York Times, 27 August 2016)

An important point of discussion in data was the status of Islam and Muslims in 'our' societies. Criticisms toward France and its seemingly ever-lasting troubled relations with Muslims was countered by discourses of inclusion towards Muslims and Islam. Similarities between Western and Muslim practices were emphasized and bridged the gap between 'us' and 'them'. Indeed, Muslims living in countries from the newspapers analyzed were presented as active economic actors, consumers, beach-lovers, parents, the elderly. Portrayals of Muslims through the lens of daily activities enabled construction of a group with similar needs and demands as 'us'. The following extract illustrates what the normalized figure of the Western Muslims entails:

It's not just clothes and fashion that the religious are adapting to meet the needs they have as western Muslims. You can watch non-swearing stand-up comedians joke about 'flying while Muslim', as you eat turkey bacon on your pizza and drink non-alcoholic beer. (Woodlock, The Guardian, 25 August 2016) 
Western Muslims were constructed in data as a group with which we can identify and that we can therefore accept. This was further emphasized by the representation of their practices as practical rather than ideological or religious. In particular, the burkini was presented as an ordinary product associated with ordinary practices - as in the story of this older woman taking care of her arthritis in a colorful outfit:

Just after 8 am, the sun was already beating down on Nice's Carras beach and Dalila, a French pensioner, was treading water in the sear in her pink and purple floral burkini. 'I spend a long time in the water every morning, to ease the pain from the arthritis in my hands and feet,' she said. 'A dip in the sea soothes the aches and makes all the difference to my health.' But since last week, Dalila has been trying to arrive at the beach much earlier-6am, if she can-before the municipal police begin their patrols. (Chrisafis, 26 August 2016, The Guardian)

Similarly to this quote, several articles tended to de-religionize the burkini by emphasizing its practical sides and casting light on individual trajectories. Typically, discussions in the data drew attention to the practices enabled by the burkini rather than the symbols it conveys. The Muslim voices heard in the data used similar strategies to de-religionize the burkini, such as the creator of the burkini, Aheda Zanetti, whose words were shared across newspapers:

and anyone can wear this, Christian, Jewish, Hindus. It's just a garment to suit a modest person, or someone who has skin cancer, or a new mother who doesn't want to wear a bikini, it's not symbolising Islam. (Zanetti, 24 August, The Guardian)

Positive representations of the burkini and of Western Muslims in the data countered images of France discriminating against Muslims and being a closed society. Positively representing the burkini as an acceptable and accepted difference also enabled construction of positive representations of Western societies as inclusive and tolerant. Positive representations of the burkini and of Western societies were therefore mutually constructive and underpinned by discourses of integration. Furthermore, explicit criticisms towards France's assimilation policy in 
relation to the burkini ban suggested opposite positive assumptions about 'our' integration policies and their outcomes. The following extract illustrates the construction of the burkini as a positive example of Western Muslims working to fit in:

These, along the burkini, are examples of how Muslims are evolving and adapting to living Western lives. Stretching extra material around your arms, legs and head is not the provocative symbol of foreign subjugation. (Woodlock, 25 August 2016, The Guardian)

Overall, positive representations of the burkini downplayed its religious meaning and constructed it as a solution for Muslims to engage in normal activities. Thus, positive representations of the burkini can be interpreted as a form of reverse stereotype that positively constructs the burkini and Muslims associated with that practice. Even though positive depictions offer alternative representations of Muslims and Islam, they do so in a limited manner by producing instances of 'appropriate difference' (Hall, 1997: 273). That is, the burkini was unanimously supported throughout the data because it was depicted as having no strong ideological nor religious added connotations - also in the words of those who wear it. As the following quote suggests, the burkini is (and should be) acceptable because it does not disrupt the existing ways of life:

The burkini is not a political project, but will become one if it is banned. ... Burkini-clad women aren't enslaved or political projects - they're just women who are retaining their modesty while having fun by the pool or at the beach. (Khan, 24 August 2016, The Globe and Mail)

The burkini is presented as a reflection of Western Muslims conforming to existing routines and structures. Thus, the burkini symbolizes the maintenance of a hierarchical order and a unidirectional adaptation path through which our ways of life remain the dominant model for Muslims to negotiate. The burkini stands as a successful negotiation because it does not question that status-quo order and suggests an effort from the minority. The notion of 'acceptable difference' therefore hints at the interplay between the burkini being framed as a difference but 
tacitly constructed as similar to our practices. In addition, the acceptance of that 'appropriate difference' enables to reinforce positive representations of 'our' societies as accepting and welcoming.

\section{Constructing cultural realities}

Similarities and differences were constructed in the data at national and transnational levels. Nuances between these levels and ways in which they become meaningful offer insights into the dialogical construction of cultural realities. In some instances, as in the following extract, explicit references to national culture corresponded to the imagined audience of which newspapers are traditionally constructive:

I would like to see face veils outlawed in Britain for the simple reason that this is, and always has been, a culture in which we have an expectation and a right to look one another in the eye during public life. (Woods, 25 August 2016a, Daily Telegraph)

However, in several articles, reflections on 'our' lifestyles were more vague and did not hint at specific entities. In the following quotation, the 'we' suggests commonalities shared at the national level but without limiting them to that scope:

It may not feel that way, but we are safer than we have ever been as we go about our daily lives, and appalling though every act of terrorism is - and, indeed, every violent crime - the odds of any of us experiencing either is very low. But we feel scared. And we feel powerless. So we blame the EU, refugees, the burkini. And we look back to what now seems a safer, happier time, when all we had to worry about was hemlines. (Garratt, 24 August 2016, The Guardian)

Besides instances of similarities constructed along one aspect, the data offered insights into multidimensional representations of sameness. Repeated tensions appeared between limiting the burkini ban to France by essentializing it as a French issue, and treating the French case as somewhat representative of 'our' challenges as well. Some articles explicitly represented France 
as 'the epicenter of the clash between extremist Islam and Western societies.' (Cohen, 18 August 2016, The New York Times). Other articles, as in the following extract, drew parallels between different cultural realities when discussing countries that have followed the French example (or are tempted to) in terms of prohibiting certain forms of veiling:

Yet the proposals now being floated in Germany around restricting the burqa make it clear that France is not the only European country grappling with whether some Islamic coverings amount to a barrier to the full participation of women in Western society. (Smale, 19 August 2016, The New York Times)

The previous quote from The New York Times brings together different levels of cultural realities, national (i.e. France, Germany) as well as transnational (i.e. European, Western). From North America, constructing issues associated with the burkini ban as a European problem highlighted symbolic differences among the West. That is, national countries in Europe were constructed separately and constructive of a European cultural reality embedded in the West but different from the contexts described in the United States or Canada. The representation of the burkini as a European issue for instance hinted at the position of the United States and Canada as experienced lands of immigration and integration, in contrast with European countries.

Therefore, European and North American cultural realities were mutually constructive in the data. The following quote illustrates the condescending tone that characterized some of the articles and through which 'us' and 'them' were covertly and simultaneously constructed:

The controversy has even lapped at these shores, with a Quebec opposition party, and some of the province's political commentators, demanding a ban. The Coalition Avenir Québec soon reversed course, perhaps recognizing the absurdity of its position. To their credit, Premier Philippe Couillard and Prime Minister Justin Trudeau offered the correct response: We have real problems to worry about, and an alleged excess of clothing while swimming is not one of them. (Globe editorial, 24 August 2016, The Globe and Mail) 
In the British and Irish newspapers, similarities noted among Germany, Belgium, Spain, the Netherlands and France were used as a reflexive exercise on the situation in the UK and the Republic of Ireland. Thus, even if differences with other European countries were mentioned in the data from the UK and the Republic of Ireland, these countries were nevertheless embedded in a European ensemble through the assumption that what happens there could happen here. The following quote illustrates the parallel drawn between here and there that contributes construction of a European reality:

This summer the burkini has been banned in Corsica, Cannes and Villeneuve-Loubet. My sister-in-law returned from a family holiday in Alicante in Spain and related how local residents tried to prevent her swimming in the pool, even going to the trouble of organising a public meeting because her costume was "too covering". Police had to intervene, proving that even on holiday there is no respite from the hysteria. Our very own Ukip has now also called for a ban on the veil. (Yaqoob, 16 August 2016, The Guardian)

Similarities and differences between individuals, cities, countries, and larger regions were mentioned across the data and contributed to constantly (re)invention of meaningful entities. Thus, cultural realities were constructed through the way they were positioned in relation to one another. This process illustrates a dialogic construction whereby the meanings of national and transnational dimensions are not fixed but constructed through their interactions (Hall, 1997). The dialogic construction of cultural realities was further emphasized in the data through the repositioning of 'others'. Muslims, who were presented as France's 'other' because of constant discrimination, were integrated with 'us', while France was cast away and associated with countries traditionally represented as 'our' enemies.

Processes involved in the construction of cultural realities therefore revealed both fluidity and solidity. The findings indicated the tensions associated with the exclusion of France from the traditional realm of commonalities and with the complementary redefinitions of 'us'. Discourses 
about the burkini ban reversed traditional discourses of exclusion-inclusion by casting France away and welcoming Muslims in. This aspect underlines the liquid aspect of cultural realities that are constantly negotiated, asserted, and can be fiercely challenged or dislocated in discourses. What was striking from the findings was the strength and unanimous condemnation of France across countries and newspaper genres, which also hints at the construction of positive self-images of tolerance. Similarities with France may have enhanced the inclination to sharply condemn it and the ban. All of the countries included in the data collection have passed measures to limit the visibility of Islam in public places. Moreover, the image of France as somewhat representative of the challenges faced by the West was present in the data. Thus, constructing France as the deviant other may have been a way of creating distance not only with France but also with one's own issues and past. The quasi-unanimous rejection of France could thus reflect the inclination of putting forward representations of 'us' as tolerant and inclusive societies-in contrast with past measures adopted against the visibility of Islam and criticisms of anti-Muslim racism (Byng, 2010; Carr and Haynes, 2015).

Despite apparent fluidity, processes of negotiating cultural realities were, however, limited. Even though France was discarded, the cultural reality from which it was excluded was not deeply challenged. That is, Muslims and their practices were included on the basis of their similarities and compliance with an existing cultural and societal order. Specifically, Western Muslims were incorporated into 'our' cultural reality, and so was the burkini, through representations that focused on similarities between Islam and the West. In addition, France was excluded based on the transgression of values such as freedom, tolerance, and equality that were associated with the West and, in particular, with the countries from which the data was collected. Thus, even though symbolic barriers were rearticulated, they were on the basis of the same 
underlying cultural reality and the hierarchy it entails. In addition, the representation and inclusion of Western Muslims seemed to be limited to the more liberal newspapers (i.e. The New York Times, The Guardian, The Irish Times, The Globe and Mail), while other outlets prioritized criticizing France. This study therefore draws attention to the limitations of challenging and redefining cultural realities in depth as discourses may hint at superficial changes and prioritize a rhetoric of exclusion (i.e. of France) over inclusion (i.e. of Muslims).

\section{Conclusion}

This study used the case of the burkini ban in France in August 2016 to explore processes associated with the construction of cultural realities. Specifically, this article explored the construction of similarities and differences in foreign (i.e. from the United States, Canada, United Kingdom, the Republic of Ireland) newspaper articles discussing the burkini ban passed in some French cities.

Findings indicate that similarities and differences were constructed across national and transnational levels using various strategies. Essentializing and stereotyping France was used to construct the burkini ban as a typical French event, which enabled dismissing the ban and to exclude France from the realm of the West. On the other hand, Muslims and Islam were associated with 'us' through the figure of the Western Muslim and the construction of the burkini as 'appropriate difference'. Muslims and the burkini tended to be represented through concrete and relatable individual experiences that downplayed religious aspects while highlighting similarities between 'us' and 'them'. Similarities and differences were therefore re-organized in the data. France, a longtime ally, became the deviant other while Muslims and Islam were normalized and presented in a similar light to 'us'. Differences (with France) and similarities 
(with Muslims and Islam) were constructive of who 'we' are by indicated what behaviors and values are perceived as normal and valuable. These new mappings of 'us' and 'them' suggested both liquid and solid aspects of cultural realities. On the one hand, existing commonalities were altered. The different levels at which similarities and differences were constructed hinted at the dialogical construction of cultural realities whereby entities become meaningful in relation to one another and through their re-positioning. However, the cultural reality from which France was excluded was not changed and Western Muslims were welcomed because they did not challenge the existing order.

This study analyzed the case of the burkini ban in-depth, thus limiting the findings only to this event. Nevertheless, results offer insights into the construction of cultural realities and articulations of similarities and differences that are worth exploring further in the light of current geopolitical tumultuous events. This study also contributed to discussions about the notion of difference, which is central to a wide range of (popular, academic, political) discourses that tend to associate it with difficulties and conflicts. Findings from this study indicate tensions and fluidity associated with the construction of difference as deviant and/or appropriate. This calls for further research to understand how difference can sometimes be constructed as acceptable and for what purposes. 


\section{References}

Adrian M (2009) France, the veil and religious freedom. Religion, State \& Society 37(4): 345374. doi:10.1080/09637490903315385

Anderson B (1991) Imagined communities: Reflections on the origin and spread of nationalism (2nd edition). London: Verso.

Appadurai A (2006) Fear of small numbers: An essay on the geography of anger. Durham, NC: Duke University Press.

Baubérot J (2007) La représentation de la laïcité comme ‘exception française’ [Representation of laïcité as 'French exception']. Cosmopolitique 16: 119-132.

Baubérot J and Milot M (2011) Lä̈cités sans frontières [Secularism without borders]. Paris: Seuil.

Baumann G (1996) Contesting culture: Discourses of identity in multi-ethnic London. Cambridge: Cambridge University Press.

Bhandar B (2009) The ties that bind: Multiculturalism and secularism reconsidered. Journal of Law and Society 36(3): 301-326. doi: 10.1111/j.1467-6478.2009.00469.x

Boeije H (2010) Analysis in qualitative research. London: Sage.

Brubaker R (1992) Citizenship and nationhood in France and Germany. Cambridge Mass.: Harvard University Press.

Byng MD (2010) Symbolically Muslim: media, hijab, and the West. Critical Sociology 36(1): 109-129. doi:10.1177/0896920509347143

Carr J and Haynes A (2015) A clash of racializations: The policing of 'race' and of anti-Muslim racism in Ireland. Critical Sociology 41(1): 21-40. doi: 10.1177/0896920513492805 
Cervulle M (2013) The use of universalism. 'Diversity Statistics' and the race issue in contemporary France. European Journal of Cultural Studies 17(2): 118-133. doi: $10.1177 / 1367549413508097$

Chrisafis A (2016). Sadness, anger and fear: how Nice is responding to the burkini ban. The Guardian, 26 August.

Cohen R (2016) France has the burkini blues. The New York Times, 18 August.

Courrier international (2016) Vu de l'étranger. Burkini : la France se trompe de combat, 17 August.

De Cillia R, Reisigl M and Wodak R (1999) The discursive construction of national identities. Discourse \& Society 10(2): 149-173. doi: 10.1177/0957926599010002002

Delphy C (2016) How a legal misunderstanding is fuelling France's witch-hunt of Muslim women. The Guardian, 29 August.

Deltombe T and Rigouste M (2006) L'ennemi intérieur : La construction médiatique de la figure de l'Arabe' [The interior domestic: The mediatic construction of the figure of the 'Arab']. In: Blanchard $\mathrm{P}$ and Bancel $\mathrm{N}$ and Lemaire $\mathrm{S}$ (eds) La fracture coloniale : La société française au prisme de l'héritage colonial. Paris: la Découverte, pp. 195-203.

Dervin F and Risager K (2015) Researching identity and interculturality. New York London: Routledge.

Doyle NJ (2011) Lessons from France: Popularist anxiety and veiled fears of Islam. Islam and Christian-Muslim Relations 22(4): 475-489. doi: 10.1080/09596410.2011.606194

Ebner J (2016) Ban a sad sign of liberalism going backwards in France. Irish Independent, 27 August. 
Fellag N (2014) Muslim label: How French North Africans have become ‘Muslims' and not 'Citizens'. Journal on Ethnopolitics and Minority Issues in Europe 13(4): 1-25.

Garratt S (2016) The burkini ban: What it really means when we criminalise clothes. The Guardian, 24 August.

Geisser V and Zemouri A (2007). Marianne et Allah: Les politiques Français face à la question Musulmane [Marianne and Allah: French Politicians Face the Muslim Question]. Paris: Éditions La Découverte.

Gilroy P (1992) The End of Antiracism. In: Donald J and Rattansi A (eds), 'Race', Culture and Difference. London: Sage, pp. 49-61.

Globe Editorial (2016) If you're worried about terrorism, please don't call the fashion police. The Globe and Mail, 24 August.

Hall S (1992) The West and the Rest: discourse and power. In: Hall S and Gieben B (eds) Formations of Modernity. Milton Keynes: Open University Press, pp. 275-332. Hall S (1997) The spectacle of the 'Other'. In: Hall S (ed) Representation: Cultural representations and signifying practices. London: Sage Publications, pp. 223-290.

Hall S, Held D and McGrew A (1992) Modernity and Its Futures (eds) Cambridge, UK: Polity Press/Open University.

Hancock C (2008) Spatialities of the secular geographies of the veil in France and Turkey. European Journal of Women's Studies 15(3): 165-179. doi: 10.1177/1350506808091502 Holliday A (2010) Complexity in cultural identity. Language and Intercultural Communication 10(2): 165-177. doi: 10.1080/14708470903267384

Holliday A (2016) Studying culture. In: Hua Z (ed) Research Methods in Intercultural Communication: A Practical Guide. Malden, MA: John Wiley \& Sons, pp. 23-36. 
Huntington SP (1996) The Clash of Civilizations and the Remaking of World Order. New York: Simon \& Schuster.

Irish Independent (2016) France's top court overturns controversial burkini ban, 26 August.

Jugé TS and Perez MP (2006) The modern colonial politics of citizenship and whiteness in France. Social Identities 12(2): 187-212. doi: 10.1080/13504630600583387

Khan S (2016) The personal politics of wearing a burkini. The Globe and Mail, 24 August.

Laoukili A (2005) Rapports de domination, laïcité et relations interculturelles [Ratio of domination, laïcité and intercultural relations]. Connexions 83: 79-98. doi: 10.3917/cnx.083.0079

Lentin A (2004) The problem of culture and human rights in the response to racism. In: Titley G (ed) Resituating culture. Strasbourg: Council of Europe, pp. 95-104.

Mallick H (2016) Yes to the burkini, and also no. Toronto Star, 29 August.

Mason D (2000) Race and Ethnicity in Modern Britain. Oxford, UK: Oxford University Press.

Miera F and Sara Pala V (2009) The construction of Islam as a public issue in western European countries through the prism of the Muhammad cartoons controversy A comparison between France and Germany. Ethnicities 9(3): pp. 383-408. doi: $10.1177 / 1468796809337430$

Mortimer G (2016) Burkini's a symbol of divisiveness: Opposing view. USAToday, 28 August. Moore K, Mason P and Lewis JMW (2008) Images of Islam in the UK: The representation of British Muslims in the national print news media 2000-2008. Cardiff: Cardiff School of Journalism, Media and Cultural Studies.

Nougayrède N (2016) The burkini ban ruling is a start, but France has more issues to deal with. The Guardian, 26 August. 
Pearson A (2016) Burkinis? Here's why we should fight them on the beaches. Daily Telegraph, 30 August.

Piller I (2011). Intercultural communication: A critical introduction. Edinburgh: Edinburgh University Press.

Poole E (2002) Reporting Islam: Media Representations of British Muslims. London: I.B.Tauris.

Raveaud M (2008) Culture-blind? Parental discourse on religion, ethnicity and secularism in the French educational context. European Educational Research Journal 7(1): 74-88. doi: 10.2304/eerj.2008.7.1.74

Richardson J (2010) British Muslims in the broadsheet press: A challenge to cultural hegemony? Journalism Studies 2: 221-242. doi: 10.1080/14616700120042097

Rubin AJ (2016) Fighting for the 'Soul of France' More towns ban a bathing suit: The burkini. The New York Times, 17 August.

Rubin AJ (2016) From Bikinis to Burkinis, Regulating what women wear. The New York Times, 27 August.

Saeed A (2007) Media, racism and Islamophobia: The representation of Islam and Muslims in the media. Sociology Compass 1(2): 443-462. doi: 10.1111/j.1751-9020.2007.00039.x

Said E (1978) Orientalism. New York: Random House.

Silverman D (2011) Credible Qualitative Research. In Interpreting Qualitative Data. A Guide to the Principles of Qualitative Research (4 ${ }^{\text {th }}$ edition). London: Sage, pp. 352-394.

Smale A (2016) Germany, Like France, Questions Place of Islamic Veils in Its Society. The New York Times, 19 August. 
Sommier M (2016) Constructing the secular imagined community: A critical intercultural analysis of discourses of laïcité from Le Monde. PhD thesis, University of Jyväskylä, Finland.

Sommier M (2017) Representations of individuals in discourses of laïcité from Le Monde: Confirming or challenging the republican framework of identity? Social Identities 23(2): 232-247. doi: 10.1080/13504630.2016.1179569

Taub A (2016) France's 'burkini' bans are about more than religion or clothing. The New York Times, 18 August.

The Globe and Mail (2016) If you're worried about terrorism, please don't call the fashion police, 24 August.

The Guardian (2016a) Mayors of Cannes bans burkinis on resort's beaches, August 11.

The Guardian (2016b) The Guardian view on France's 'burkini bans': ugly politics on the beach, 24 August.

The New York Times (2016) The Latest Valls Burkini ruling won't end vital debate, 26 August. USAToday (2016) France's fashion police: Our view, 28 August.

Vanparys N, Jacobs D and Torrekens C (2013). The impact of dramatic events on public debate concerning accommodation of Islam in Europe. Ethnicities 13(2): 209-228. doi: $10.1177 / 1468796812470899$

Veille S (2016) "Burkini": Retour sur une polémique aux confins du droit et de l'absurde. Mediapart, 29 August.

Yakabuski K (2016) With burkini bans, France buries its head in the sand. The Globe and Mail, 22 August. 
Woodlock R (2016) All hail the burkini's blend of Islamic values and western lifestyle. The Guardian, 25 August.

Woods J (2016a) Being for the Burkini ban on beaches doesn't make me anti-women. Daily Telegraph, 25 August.

Woods J (2016b) Burkinis on the beach just an act of provocation? The Irish Independent, 28 August.

Yaqoob S (2016) Abuse of Muslims is now mainstream. I never thought my children would see this. The Guardian, 16 August.

Zanetti A (2016) I created the burkini to give women freedom, not to take it away. The Guardian, 24 August. 